\title{
Local biodiversity conservation in Sigi, Central Sulawesi, Indonesia: Analysis of the effect of elevation, land accessibility, and farmers' income and perception on vegetation diversity in agroforestry systems
}

\author{
NINA DWI LESTARI ${ }^{1,2, \bullet}$, DIDIK SUPRAYOGO' ${ }^{1}$, ARIEF RACHMANSYAH ${ }^{2}$ \\ ${ }^{1}$ Program of Environmental Resources Management, Multidisciplinary Program of Natural Resources Management, Program of Graduates, Universitas \\ Brawijaya. Jl. Veteran No. 1 Malang City 65145, East Java, Indonesia \\ ${ }^{2}$ Department of Soil Science, Faculty of Agriculture, Universitas Brawijaya. Jl. Veteran No. 1 Malang City 65145, East Java, Indonesia. Tel.: +62-341- \\ 551665, 565845, Fax.: +62-341-560011, ’email: ninadwilestari13.ndl@ gmail.com; nd.lestari@ub.ac.id \\ ${ }^{3}$ Department of Civil Engineering, Universitas Brawijaya. Jl. M.T. Haryono No.167, Malang City 65145, East Java, Indonesia
}

Manuscript received: 3 June 2017. Revision accepted: 29 December 2018.

\begin{abstract}
Lestari ND, Suprayogo D, Rachmansyah A. 2018. Local biodiversity conservation in Sigi, Central Sulawesi, Indonesia: Analysis of the effect of elevation, land accessibility, and farmers' income and perception on vegetation diversity in agroforestry systems. Biodiversitas 19: 283-291. The objectives of the research were to evaluate the level of landscape vegetation diversity in agroforestry systems and to determine the effect of elevation, accessibility, and farmer's income and perception on vegetation diversity in agroforestry systems. The research was conducted in Sigi District, Central Sulawesi, Indonesia. The method used was the Multidisciplinary Landscape Assessment approach. The research sites were located in 3 districts and 6 representative villages i.e. Padende and Sibedi in the lower landscape (23-75 m asl.), Balane and Doda in the middle landscape (148-504 $\mathrm{m}$ asl.), Dombu and Ongulero in the upper landscape (1163-1404 m asl.), with 5 replications in each village. The total area of the six villages was 3772.13 ha that consisted of 1217.13 ha of agroforestry systems (32.3\%). The research covered a population of 392 households who had landed with agroforestry systems. A total of 30 agroforestry farmers and their land (minimum 0.25 ha, homogeneous land system) were selected as samples. Research activities like observation, survey, and analysis were divided into two aspects, namely biophysical and socioeconomic aspects. The results revealed that at landscape level agroforestry systems had relatively high plant species diversity $\left(\mathrm{H}^{\prime}=\right.$ 3.1) and needed to be optimized to enhance its role as buffering zone for biodiversity conservation and for supporting sustainable livelihood. Efforts to improve vegetation diversity must be adjusted to habitat conditions (elevation and soil health), where vegetation can grow and produce well. The regional development such as accessibility improvement is still needed and it will not threaten the vegetation diversity as long as there is a harmony between human activities and the environment. An increase in the level of income with a positive perception of farmers on the benefits of vegetation diversity in the future will have a main role in vegetation diversity conservation as fundamental asset in sustainable development.
\end{abstract}

Keywords: Agroforestry, accessibility, elevation, perception and income, Vegetation Diversity Index

\section{INTRODUCTION}

The challenge to conserve vegetation diversity in a heterogeneous landscape has resulted in a need to promote and manage conservation within anthropogenic ecosystem (Halladay and Gilmour 1995; Collins and Qualset 1999). Vandermeer and Perfecto (1995) and Altieri (1999) discussed two main types of vegetation diversity, associated with agro-ecosystems, called planned vegetation diversity and unplanned vegetation diversity. Planned vegetation diversity refers to the components of the agroecosystem purposely introduced, or grown by a farmer. Unplanned vegetation diversity comprises those organisms that colonize the agroecosystem without direct mediation from its human managers (e.g., volunteer plants, wildlife, etc.). However, farmers generally choose to either keep or remove this associated vegetation diversity as part of their agricultural management. Thus, agroecosystem, such as agroforestry that is well known as a global future land use system, has an important role in conserving vegetation diversity (Nair and Garrity 2012).
The level of high biodiversity in the wet tropical area, especially in Sulawesi is degrading due to the high rate of population growth and regional development (Cannon et al. 2007). Agroforestry systems located outside of the protected forest in Sulawesi can be used as a strategy to enhance biodiversity conservation and are believed to be able to support sustainable agriculture (Bos and Sporn 2013). The agroforestry systems with high biodiversity are believed to be able to overcome the trade-off between production for generating income and conservation for providing environmental services. They are needed to support communities' welfare. All the efforts and conservation strategies must be developed for the purpose of reducing threats to the biodiversity. The main focus of this research was to improve the understanding of the patterns and processes of ecosystems across different landscapes, enabling more accurate prediction of the impact of human activities on biodiversity and efforts to control damage to biodiversity through land use management, such as the implementation of agroforestry. Apart from conservation strategy, which is used to 
determine the priority areas and the scale at which the strategy is applied, this research is expected to give comprehensive data analysis, in order to reduce the threat of human activity on biodiversity in regional development, with problem definition focused on vegetation.

The objectives of this research were to evaluate the level of biodiversity in agroforestry systems in the landscape, as conservation corridors and to determine the effects of elevation, land accessibility, farmers' income and their perceptions on the vegetation diversity indexes. Results of this research can be used to (i) provide baseline research data of vegetation diversity in the agroforestry systems, in support of environmental conservation, (ii) provide practical recommendations for policy-makers, in formulating management strategies related to environmental resources, and (iii) provide practical recommendations for the community in order to understand the importance of the diversity of vegetation for improving of the environment and their welfare.

\section{MATERIALS AND METHODS}

\section{Study area}

The research was carried out between July 2014 and February 2016 in Sigi District, Central Sulawesi, Indonesia. This region has an area of approximately $5196.02 \mathrm{~km}^{2}$, and is located in latitude between $0^{\circ} 52^{\prime} 16^{\prime \prime}$ and $2^{\circ} 03^{\prime} 21^{\prime \prime} \mathrm{S}$ and longitude between $119^{\circ} 38^{\prime} 45^{\prime \prime}-120^{\circ} 21^{\prime} 24^{\prime \prime}$ E. The research sites were located in six representative villages, i.e. Padende (PA) and Sibedi (SI) of Marawola Subdistrict in the lower landscape (23-75 m asl.), Balane (BA) and Doda (DD) of Kinovaro Subdistrict in the middle landscape (148$504 \mathrm{~m}$ asl), Dombu (DB) and Ongulero (ON) of West Marawola Subdistrict in the upper landscape (1163-1404 m asl) with 5 plots as replications in each village. The total area of the six villages was 3772.13 hectares which consisted of 1217.13 hectares of agroforestry systems (32.3\%). The research covered a population of 392 households who had landed with agroforestry systems. A total of 30 agroforestry farmers and their land (minimum of 0.25 ha and homogeneous land systems) were selected purposively as samples, but the plots to get vegetation data were located randomly within the selected land.

\section{Procedures}

Concepts and research variables

The method used was the Multidisciplinary Landscape Assessment approach. Research activities such as observation, surveys, and analysis consisted of two aspects, namely biophysical and socioeconomic aspects. The geo position (elevation and location coordinates) of each plot of agroforestry selected for characterization purpose was recorded in order to activate the feature of tracking Global Positioning System (GPS) to aid the calculation of estimated distances from the closest farm roads and landowners' houses to the connective points in agroforestry plots. The main activities in this study included observation of agroforestry systems as well as biophysical measurement and socio-economic surveys of agroforestry farmers. The biophysical surveys were the those for the characterization of biological diversity agroforestry in different elevations in the landscape, soil sampling and litter, a survey of accessibility, while the social and economic surveys were those to characterize the welfare of agroforestry farmers as well as observation of the perception of the public, especially agroforestry farmers understanding about the importance of agroforestry systems and their benefits in the management of agroforestry systems.

\section{Data collection techniques}

Data of plants at various stages of growth, namely tree sprouts, seedlings, saplings, and poles, and large tree were collected using quadrats $\left(1 \mathrm{~m}^{2}, 4 \mathrm{~m}^{2}, 25 \mathrm{~m}^{2}, 100 \mathrm{~m}^{2}\right.$, and $\left.400 \mathrm{~m}^{2}\right)$ nested in a transect $(20 \times 100) \mathrm{m}$. Analysis and identification activities of plant samples were conducted in Herbarium Celebense (CEB) Palu, Tadulako University. Subsequent findings of several samples of rare and endemic plants were preserved following the "Schweinfurth Method" and using "Brahms method" (Biodiversity Research and Herbarium Management System method). Other agroforestry characteristic data recorded were the level of complexity of agroforestry (relative basal area and percentage of canopy cover), the input litter and its thickness in each plot.

In addition to the vegetation sampling, soil sampling was also conducted to determine soil quality and its characteristics related to soil health. Soil analysis was conducted in Soil Laboratory of Tadulako University and Laboratory of Soil Biology and Soil Physics in Brawijaya University, Malang, Indonesia. Measurements were conducted to get data of the land accessibility associated with agroforestry and road density $\left(\mathrm{km} \cdot \mathrm{ha}^{-1}\right)$, access of a farmer's house to the land $(\mathrm{m})$, distance from land (point belt) to the farm road nearby $(m)$. Accessibility to the public was assessed with percentage comprehensive settlement (settlement area per unit area of the village) and the estimated distance from the village center to the main market city $(\mathrm{km})$.

Socio-economic survey activities were done to get data of the farmer's welfare and perception on agroforestry systems. The observation of farmers' perceptions about vegetation diversity and it's value in agroforestry systems was done using Focus Group Discussion (FGD) technical method based on Rapid Appraisal (RABA) method developed by World Agroforestry Centre and also Pebble Distribution Method (PDM) through Multidisciplinary Landscape Appraisal developed by CIFOR. Respondents in FGD activities represented three groups (women, men, and children) and in-depth interviews were done based on the functional groups.

\section{Data analysis}

Vegetation data were analyzed to determine the indexes of importance value (Iv), Shannon-Wiener's species diversity (H'), Simpson's species dominance (Ds), Simpson's species diversity (D) and its maximum diversity (D Max), Margalev's species richness (R), evenness (E) and Morisita's population distribution (Id). The description 
of vertical vegetation structure was based on drawings of vertical stratification of canopy trees. All qualitative data resulting from the socio-economic survey activities were quantified by scoring method and analyzed using the sustainable livelihood approach (SLA) method.

All quantitative data were analyzed using ANOVA. The data varied if the results of analyses were significant ( $p$ $<0.05)$, then analyses were continued with another test, Fisher's protected LSD. Correlation between variables was determined using correlation and simple regression analyses. Analysis tools used were MS Excel, GENSTAT 18th Edition, SPSS 16th edition, Principle Component Analysis-PAST 1.34th Edition, Ecological methodology (Krebs 2003) for data tabulation, verification, validation, and statistical test. The image data were analyzed using Adobe Photoshop to count canopy cover percentage, and Corel Draw X5 to figure out the tree distribution images, both vertical and horizontal views.

\section{RESULTS AND DISCUSSION}

\section{Characteristic of agroforestry systems related to vegetation diversity}

The agroforestry systems in Sigi can become a buffer for conservation areas, because their vegetation composition and structure contain many species of trees, some of which forest trees endemic to this area. At the landscape scale, Table 1 shows the characteristics of agroforestry systems in term of vegetation diversity. The overall diversity at the level of landscape was high $(\mathrm{H} '=$ 3.1 ), consisting of 123 plants species, dominated by Theobroma cacao (upper landscape) and Cocos nucifera (middle and lower landscape). The species belong to 48 families, codominated by Fabaceae and Moraceae. The Shannon-Wiener's diversity index in the upper landscape was categorized as medium $\left(\mathrm{H}^{\prime}=2.84\right)$, slightly higher than in middle landscape $\left(\mathrm{H}^{\prime}=2.47\right)$ and lower landscape $\left(\mathrm{H}^{\prime}=\right.$ 2.28). The vegetation diversity index, at the plot level, varied from very low $\left(\mathrm{H}^{\prime}=0.9\right)$ to medium $\left(\mathrm{H}^{\prime}=2.7\right)$, below the optimal diversity, based on Simpson's Diversity Index (D/Dmax ratio). So, it is necessary to increase vegetation diversity starting at the landscape level to $8-19 \%$ and at the plot level to $7-44 \%$.

In addition to Cocos nucifera (coconut) and Theobroma cacao (cocoa), several other species of plants dominated in plot level of agroforestry system, namely Musa paradisiaca (banana), Aleurithesmoluccana (pecan), Coffea canephora (coffee), Gliricidia sepium (gamal), Erythrina subumbrans (dadap), Agathis dammara (white damar or damar malolo) and Metroxilon sago (sago). Each of these species had an Importance Value Index (IVI) ranging from $45 \%$ to $183 \%$. The most dominant species have the highest influence in determining the characteristic of the vegetation. The uses and importance value index of dominant species in agroforestry systems are described in Table 2.

The value of the Morisita index (population distribution of all trees) revealed that $23 \%$ of the 30 plots had uniform tree distribution ( $\mathrm{Id}<0.75$ ), and the remaining $77 \%$ of plots had relatively random distribution, and only $3 \%$ of plots had clumped distribution pattern. The results showed that the trees in the agroforestry systems were generally distributed randomly. Based on the vertical distribution of canopy, there were 3-6 strata in agroforestry systems. Tree canopy layers generally had four strata and were concentrated in zone $\mathrm{C}$ (at a height of 4-20 m); $7 \%$ of the plots were found to have 6 strata, resembling layered canopy of forest landscapes, in the middle and upper and $17 \%$ of the plots had a tree canopy reaching zone A (height $>30 \mathrm{~m}$ ). Agroforestry systems should be optimal in the role of biodiversity conservation if the structure and composition of vegetation resemble a forest ecosystem. But in Sigi nowadays many agroforestry systems have not been optimal in quality, so that management actions should be taken in order to maintain the structure and composition similar to those of the natural vegetation.

Table 1. The characteristics of vegetation diversity at the landscape level

\begin{tabular}{|c|c|c|c|c|c|}
\hline Variable & & $\begin{array}{c}\text { Overall } \\
\text { Landscape } \\
\text { 23-1404 m asl. }\end{array}$ & $\begin{array}{c}\text { Upper } \\
(1163-1404) \\
\text { m asl. } \\
\end{array}$ & $\begin{array}{c}\text { Middle } \\
(\mathbf{1 4 8 - 5 0 4 )} \\
\text { m asl. } \\
\end{array}$ & $\begin{array}{l}\text { Lower } \\
(23-75) \\
\text { m asl. } \\
\end{array}$ \\
\hline Dominant Tree Species & & Cocos nucifera & Theobroma cacao & Cocos nucifera & Cocos nucifera \\
\hline Importance Value Index & $\%$ & 43.83 & 48.23 & 67.73 & 73.19 \\
\hline Trees density (trees ha- ${ }^{-1}$ ) & & 572.67 & 684.50 & 417.00 & 616.50 \\
\hline Number of Species & & 123 & 73 & 56 & 60 \\
\hline Number of Families & & 48 & 38 & 25 & 25 \\
\hline Simpson's diversity index & $\mathrm{D}$ & 0.91 & 0.88 & 0.85 & 0.80 \\
\hline Shannon Wiener's diversity index & $\mathrm{H}^{\prime}$ & 3.10 & 2.84 & 2.47 & 2.28 \\
\hline Evenness Index & $\mathrm{E}$ & 0.64 & 0.66 & 0.61 & 0.56 \\
\hline Margalev's Species Richness index & $\mathrm{R}$ & 14.98 & 9.97 & 8.77 & 8.29 \\
\hline Morisita's Index & Id & 1.73 & 0.66 & 0.87 & 1.51 \\
\hline Simpson's Max. Diversity Index & Dmax & 0.98 & 0.99 & 0.98 & 0.98 \\
\hline [D/Dmax] Ratio & $\%$ & 92.18 & 89.25 & 85.99 & 81.43 \\
\hline Simpson's Dominance Index & Ds & 0.09 & 0.12 & 0.15 & 0.20 \\
\hline
\end{tabular}


Table 2. Importance value Index of dominant vegetation and its value based on farmers' perceptions

\begin{tabular}{|c|c|c|c|c|c|}
\hline Landscape & Site & Tree dominancy & $\begin{array}{l}\text { Importance } \\
\text { Value Index } \\
(\%)\end{array}$ & Uses & Parts of the plant used \\
\hline \multirow{7}{*}{$\begin{array}{l}\text { Upper } \\
(1163-1404 \\
\text { m asl.) }\end{array}$} & \multirow[t]{4}{*}{ DB } & Erythrina subumbrans & 78.77 & Shade, soil fertilizer, board, hedge, firewood & Trunk, leaves \\
\hline & & Agathis dammara & 76.52 & $\begin{array}{l}\text { Construction, produce copal, glues, varnish, } \\
\text { crafts trinkets }\end{array}$ & Trunk, resin \\
\hline & & Coffea canephora & 72.28 & Food, commercial goods, firewood & Fruit, leaves, trunk \\
\hline & & Theobroma cacao & $44.73-56.91$ & Food, commercial goods, firewood & Fruit, trunk \\
\hline & \multirow[t]{3}{*}{ ON } & Theobroma cacao & $97.77-107.01$ & Commercial goods, firewood & Fruit, trunk \\
\hline & & Agathis dammara & $70.11-75.41$ & Construction, timber, and resin & Trunk, sap \\
\hline & & Erythrina subumbrans & 65.85 & Shade, board, hedge, firewood & Trunk \\
\hline \multirow[t]{3}{*}{$\begin{array}{l}\text { Middle } \\
(148-504 \\
\text { m asl.) }\end{array}$} & \multirow[t]{2}{*}{ BA } & Cocos nucifera & $104.82-174.74$ & $\begin{array}{l}\text { Custom, construction, furniture, cosmetics, } \\
\text { commercial goods, food, windbreaker, } \\
\text { hedge }\end{array}$ & $\begin{array}{l}\text { Trunk, Frondsleaves, } \\
\text { fruit }\end{array}$ \\
\hline & & Theobroma cacao & 71.24 & Commercial goods, firewood & Fruit, trunk \\
\hline & DD & Aleurites moluccana & $52.88-134.95$ & Commercial goods, cosmetics, firewood & Fruit, trunk \\
\hline \multirow{6}{*}{$\begin{array}{l}\text { Lower } \\
(23-75 \\
\text { m asl.) }\end{array}$} & \multirow[t]{4}{*}{ PA } & Cocos nucifera & 135.47 & $\begin{array}{l}\text { Food, construction, custom, furniture, } \\
\text { handicraft }\end{array}$ & Fruit, trunk, fronds, \\
\hline & & Gliricidia sepium & 122.26 & Fodder, soil fertilizer, furniture, hedge & Trunk, leaves \\
\hline & & Musa Paradisiaca & $92.91-112.53$ & $\begin{array}{l}\text { Food, commercial goods, furniture, natural } \\
\text { coloring }\end{array}$ & Leaves, trunk, fruit \\
\hline & & Metroxylon sagu & 95.4 & $\begin{array}{l}\text { Custom, furniture, fodder, house } \\
\text { construction and panel, roof, niche of sago } \\
\text { worms (drugs), commercial goods, food }\end{array}$ & Trunk, fronds, leaves \\
\hline & \multirow[t]{2}{*}{ SI } & Cocos nucifera & 125.95-183.09 & Food, construction, commercial goods & Fruit, trunk, fronds \\
\hline & & Musa Paradisiaca & 104.05-118.07 & Food, custom, furniture, commercial goods & Leaves, trunk, fruit \\
\hline
\end{tabular}

Generally, the vegetation diversity in the agricultural landscape in Sigi (only 37\%) was high enough and able to act as a buffer zone for biodiversity conservation. A total of $10 \%$ of plots (scattered in the middle and upper landscapes) were found to have vegetation stadium of trees' sprouts with stem diameters of $<2 \mathrm{~cm}$, and $23 \%$ of plots in the lower and middle landscape vegetation stadium of seedlings with stem diameters of $2-5 \mathrm{~cm}$ and heights of $<1.5 \mathrm{~m}$. No vegetation stadium of sapling with stem diameters of $2-5 \mathrm{~cm}$ and height over $1.5 \mathrm{~m}$ was found in all plots. The young vegetation stadia (saplings, seedlings and tree sprouts) are important in the conservation of vegetation diversity, and become one of the sustainability indicators, in the management of agroecosystems, in agricultural landscapes. In maintaining the sustainability of agroforestry systems, regeneration activities are needed (both of afforestation and reforestation), especially in locations where the level of vegetation diversity on stadia of saplings, seedlings, and tree sprouts was very low.

The number of species and families and the level of vegetation diversity of all growth stadia of trees in agroforestry systems, at landscape level quite varied. A total of $87 \%$ of the 30 plots had high Evenness Index (E> 0.6); $93 \%$ had a low Dominance Index (Ds <0.4); 63\% had particularly high Simpson's Diversity Index (D>0.7); and $67 \%$ had a high species Richness Index (R>2.6). A total of $63 \%$ of the 30 observation plots had relatively low Shannon-Wiener Diversity Index $\left(\mathrm{H}^{\prime}<2\right)$, but $37 \%$ quite high $\left(\mathrm{H}^{\prime}=2-3\right)$. The similarity of species composition in each landscape as indicated by the Sorensen Index (Cs) was low ( $\mathrm{Cs}=038 \%-55 \%)$ in the overall landscape, meaning that the agroforestry system had high diversity at the landscape scale. Similarity index between the lower landscape and the middle landscape was $55 \%$, between the lower landscape and upper landscape $38 \%$, and between the middle and upper landscape $42 \%$.

The success of conservation efforts in the past, indicated by the results of survey of the forest vegetation, remained quite high. A total of $90 \%$ of plots had big trees (diameter at breast height of $>30 \mathrm{~cm}$ ); some had canopy heights up to $>30 \mathrm{~m}$, but they were only found in the upper and middle landscapes. Based on these data, vegetation diversity in agroforestry systems, at plot level, were generally threatened, or most of them varied, from very low to medium. This area has very high endemicity and needs conservation efforts to maintain it. Improvement of management in agroforestry systems is absolutely necessary to enrich the diversity of plants, and the selected species must be adapted to climate and habitat conditions. It is also important to increase tree density, maintain the canopy stratification (multilayers), improve selection techniques appropriate to vegetation types that meet the following criteria, namely long-lived, high carbon content, higher basal area with high wood density, preferably $>0.6$ and longer harvest cycle (Hairiah 2013), to get a better primary production, to improve environmental health and support farmers' welfare. 


\section{The effect of elevation on Vegetation Diversity}

Elevation is one indicator of habitat conditions that affect the level of biodiversity. Hiwot (2014) says that vegetation diversity is affected by natural changes, such as changes in habitat conditions (one of which is elevation) and the results of management measures, as a form of community activity. Meanwhile, Kessler's research (2005) stated that biodiversity was affected by the conditions of the ecosystem.

Lowland rainforest has higher diversity than the highland rainforest, as a result of the manifestation of the soil fertility conditions. In this study, elevation significantly correlated with all but one vegetation indexes, i.e., index of species richness (R), evenness (E), ShannonWienner species diversity $(\mathrm{H})$, Simpson's species diversity (D), including maximum species diversity (Dmax) and species dominance (Ds), and Importance Value Index (Table 3). Elevation did not significantly affect the distribution of tree population as shown by Morisita vegetation distribution index (Id). Morisita index (Id) indicates how farmers' management practices influence vegetation diversity. The results showed that vegetation diversity was affected by the management practices of farmers and not just the elevation.

Generally, the elevation varied (23-1404 m above sea level), and had an important effect on vegetation diversity. So it is important to conserve natural vegetation diversity in agroecosystems of different altitudes. The results revealed that higher elevation had higher vegetation diversity, and most statistical results showed a very significant correlation between vegetation diversity index and elevation. Those results supported the statement of Hiwot (2014) that most agroforestry systems, located in higher elevations were difficult to reach and a bit far from farmers' management practice and their home, and also closer to protected areas, so that they had higher vegetation diversity. Thus, agroforestry systems in the lower elevation closer to settlements and more accessible to farmers, will have lower vegetation diversity because the farmers have more chances to change the species of trees planted in the system, depending on the needs of the farmers.

\section{The effect of land accessibility on vegetation diversity indexes}

Accessibility in this research was indicated by the level of road density (length of road per hectare) in every village as a result of the physical- infrastructure development index. Accessibility index in this research was also calculated from a distance between villages, where agroforestry systems were located and the capital regency where the main market was located.

The results revealed that accessibility and road density had a very significant correlation to vegetation diversity in agroforestry systems, but the correlation was very weak. The values of $r$ were very low, and consequently, the values of $\mathrm{R}^{2}$ were even lower (Table 4), meaning that the road density could explain only very low percentage of the variation in the values of vegetation indexes. In other words, road density did not affect vegetation diversity (Table 4). Ahmed et al, (2014), who observed at the scale of small hydrological catchments showed a significant positive correlation between roadless volume (RV) as road network metric and species richness and the average number of unique species recorded at each site, but in that site forest bird community composition was also significantly affected by RV.

Higher road density may decrease vegetation diversity through fragmentation of natural habitat as supported by result of the research from Santelises and Del Castillo (2013). They revealed that development of road for increasing land accessibility in the shrubland and oak forest threatened tree diversity. The result of regression analysis (Table 4) showed that the effects of road density on vegetation diversity were not significant. These results supported the findings of Votsi (2012) that the effect of road network as accessibility index on vegetation diversity was not significant. It means that communities and their characteristics have an important role in supporting regional development that is in harmony with biodiversity conservation.

The distance from the villages to the city where the main market in the capital regency was located had a very significant correlation with vegetation diversity and the correlation was relatively strong. This result means that the distance to the main market had a very significant effect on vegetation diversity, except for Morisita's tree distribution index, which was related more to management by farmers in selecting their trees in agroforestry systems (Table 5). These results were the opposite of those of Tarvirdizadeh (2014) and Tehrani (2015), which revealed that accessibility to the main road did not show significant relationship and did not have effect on vegetation diversity, where the landscape varied and was undisturbed. In that case, site conditions in their research were supported by the good landscape conditions that were in harmony with human activities in the long term. Thus, the results of the research revealed that vegetation diversity in Sigi could be threatened by improved accessibility if the community activities are not in harmony with their environment. So, conservation of vegetation diversity to maintain environmental services, as a strategy to reach sustainable development is still needed.

\section{The effect of farmers' perceptions on vegetation diversity}

Communities in each landscape had different perceptions of the importance and value of the function of agroforestry systems in their lives. The rural Communities in Dombu and Ongulero in the upper landscape generally had the same perception that the vegetation diversity in agroforestry systems was very valuable for their lives, as stated by $65 \%$ of Dombu villagers and $55 \%$ of Ongulero villagers. Among the variables of the importance of agroforestry systems, the future variable had the highest value among Dombu villagers, or 94\%, while in Ongulero village, the variables of firewood and future had the same highest value, which was $87 \%$. In the middle landscape, the perceptions were different for each village. A total of $43 \%$ of Balane villagers had the perception that the functional value of agroforestry systems was very important, and $42 \%$ 
of Doda Villagers had the same perception. Meanwhile, in the lower landscape, the rural communities in Padende and Sibedi Villages had the same perception that the functional value of agroforestry systems was essential for their livelihood, with the scores of $35 \%$ and $47 \%$ respectively. The highest variable in Padende village was firewood, which was $55 \%$ in and the highest variable in Doda Village was construction, i.e., $73 \%$.

Regarding the value of agroforestry land, people in every landscape had a perception that exotic values $(59.3 \%)$ were more important than endemic values $(40.6 \%)$. In the use values of endemic and exotic, people in every landscape had the same perception that the economic function was the most important and was considered more influential for life than the ecological and socio-cultural functions. The people from the three landscape had the same perception that trunks and leaves were the most useful parts of plants in agroforestry systems (Figure 1). This research (Figure 2) revealed that farmers' positive perceptions of the importance and benefits of the agroforestry systems in every village in different landscapes varied from high to low in line with elevation and the data had significant differences (average \pm se $=$ $63.72 \pm 0.074)$. Farming communities in the upper landscape, based on representative villages (DB and $\mathrm{ON}$ ) had higher positive perception $(71.25 \pm 0.07)$ than in the middle $(68.90 \pm 0.07)$ and lower landscapes $(51.00 \pm 0.07)$. The lowest positive perceptions from farmers' communities were evident in the lower landscape; it showed that the representative villages (PA and SI) had only about 42-60\% positive perception. These results generally showed that positive perception reflected the community characteristic in caring for the environment, as indicated by the way they maintained and conserved their agroforestry systems. More positive perception of farmers resulted in more action to conserve their agroforestry land with higher landscape vegetation diversity.

Table 3. Vegetation Indexes influenced by elevation

\begin{tabular}{lllll}
\hline Y & A & X= Elevation (m asl) & Correlation (r) & $\mathbf{R}^{2}$ \\
\hline Total trees density (trees ha ${ }^{-1}$ ) & 381 & 0.2496 & $0.69^{* *}$ & $0.14^{* *}$ \\
Shanon Wienner trees species diversity (H') & 1.5199 & 0.000576 & $0.72^{* *}$ & $0.54^{* *}$ \\
Richness of trees species (R) & 2.291 & 0.001508 & $0.66^{* *}$ & $0.46^{* *}$ \\
Evenness of trees Species (E) & 0.6478 & 0.0000728 & $0.48^{* *}$ & $0.26^{* *}$ \\
Trees species distribution (Id) & 0.8445 & 0.0001033 & $0.19^{*}$ & $0.08 \mathrm{~ns}$ \\
Simpson species diversity (D) & 0.6789 & 0.0001070 & $0.60^{* *}$ & $0.39^{* *}$ \\
Simpson trees species dominancy (Ds) & 0.3111 & -0.000104 & $0.59^{* *}$ & $0.37^{* *}$ \\
Relative trees basal area & 0.5570 & -0.000183 & $0.50^{*}$ & $0.27^{* *}$ \\
\hline
\end{tabular}

Note: *) Data were tested regression with $95 \%$ confidence interval, where $* *$ ) is very significant, $*$ ) significant, ns=not significant

Table 4. The accessibility index (road density) and the effect on vegetation indexes

\begin{tabular}{lllll}
\hline $\mathbf{Y}$ & $\mathbf{A}$ & $\mathbf{X}=\mathbf{r o a d}$ density $\left(\mathbf{m ~ h a}^{-\mathbf{1}}\right)$ & $\begin{array}{l}\text { Correlation } \\
\text { coefficient (r) }\end{array}$ & $\mathbf{R}^{\mathbf{2}}$ \\
\hline Total tree density (trees ha $\left.{ }^{-1}\right)$ & 572.3 & -3.02 & $0.15^{* *}$ & $0.04 \mathrm{~ns}$ \\
Shannon-Wienner tree species diversity (H') & 1.945 & -0.00652 & $0.14^{* *}$ & $0.05 \mathrm{~ns}$ \\
Richness of tree species (R) & 3.407 & -0.0173 & $0.11^{* *}$ & $0.05 \mathrm{~ns}$ \\
Evenness of tree Species (E) & 1.000 & -0.732 & $0.14^{* *}$ & $0.05 \mathrm{~ns}$ \\
Tree species distribution (Id) & 0.8461 & 0.00337 & $0.15^{* *}$ & $0.13 \mathrm{~ns}$ \\
Simpson Species Diversity (D) & 0.7573 & -0.00118 & $0.04^{* *}$ & $0.04 \mathrm{~ns}$ \\
Simpson tree species dominance (Ds) & 0.2345 & 0.00117 & $0.03^{* *}$ & $0.04 \mathrm{~ns}$ \\
Relative tree basal area & 0.4096 & 0.00283 & $0.13^{* *}$ & $0.05 \mathrm{~ns}$ \\
\hline
\end{tabular}

Note: *) Data were tested regression with $95 \%$ confidence interval, where $* *)$ is very significant, $\mathrm{ns}=\mathrm{not}$ significant

Table 5. The accessibility index (distance from village to the city where the main market in capital regency located) and their effect on vegetation indexes

\begin{tabular}{lllll}
\hline $\mathbf{Y}$ & $\mathbf{A}$ & $\begin{array}{l}\mathbf{X}=\text { distance to the city } \\
(\mathbf{k m})\end{array}$ & $\begin{array}{l}\text { Correlation } \\
\text { coefficient (r) }\end{array}$ & $\mathbf{R}^{2}$ \\
\hline Total tree density (trees ha-1) & 356.1 & 6.32 & $0.68^{* *}$ & $0.31^{* *}$ \\
Shanon-Wienner tree species diversity (H') & 1.4769 & 0.01406 & $0.69^{* *}$ & $0.49^{* *}$ \\
Richness of tree species (R) & 2.204 & 0.03579 & $0.61^{* *}$ & $0.40^{* *}$ \\
Evenness of tree Species (E) & 0.6418 & 0.001796 & $0.46^{* *}$ & $0.24^{* *}$ \\
Tree species distribution (Id) & 0.8358 & 0.00256 & $0.18^{* *}$ & $0.07 \mathrm{~ns}$ \\
Simpson Species Diversity (D) & 0.6700 & 0.002647 & $0.58^{* *}$ & $0.36^{* *}$ \\
Simpson tree species dominancy (Ds) & 0.3197 & -0.002575 & $0.57^{* *}$ & $0.34^{* *}$ \\
Relative tree basal area & 0.5688 & -0.00439 & $0.46^{* *}$ & $0.27^{* *}$ \\
\hline
\end{tabular}

Note: $*$ ) Data were tested regression with $95 \%$ confidence interval, where $* *$ ) is very significant, ns $=$ not significant 


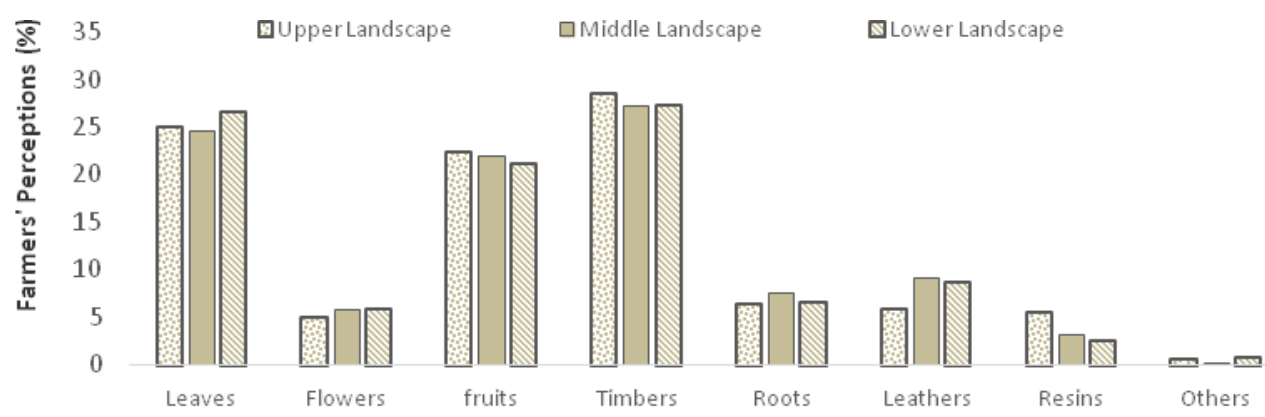

Benefits Part of Vegetation in Agroforestry and It's Function

Figure 1. Farmers' perceptions of the important benefits of vegetation diversity and its function in agroforestry system

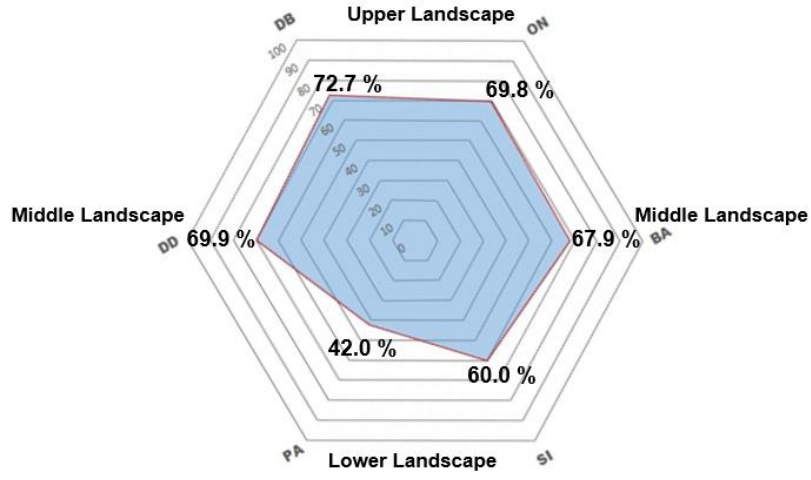

Figure 2. The assessment result of positive farmers' perceptions $[\mathrm{N}=157$ respondents] is to determine whether they understood the importance of vegetation diversity in agroforestry systems and its benefits for livelihood

The next result revealed that positive perceptions of farmers about the benefits of agroforestry systems and their function for livelihood in future had significant correlation with actual vegetation diversity, i.e., the richness of trees species $(r=0.5)$ and Shannon-Wienner trees diversity $(r=0.43)$. The perception of farmers regarding the future benefits of agroforestry systems contributed $22.4 \%$ to the variation of richness of tree species (R, Margalev index), and about $19 \%$ to the variation in Shannon-Wiener diversity index (Figure 3).

\section{The effect of farmers' income on vegetation diversity}

In the lower landscape in Padende Village analysis results of the SLA (Sustainable Livelihoods Approach) showed that the highest capital was found in the financial sector and the lowest one in the social sector, whereas in Sibedi Village the highest capital was found in infrastructure and the lowest one in Human Resources. In the middle landscape, in Balane Village, the highest capital was found in infrastructure and the lowest one in Human Resources. In Doda Village, the highest capital was found in natural resources or environment and the lowest one in social services. In the upper landscape, in Dombu Village, the highest capital was found in the financial sector and the lowest one in infrastructure. Meanwhile, in Ongulero Village, the highest capital was found in natural resources or environment and the lowest was in infrastructure.

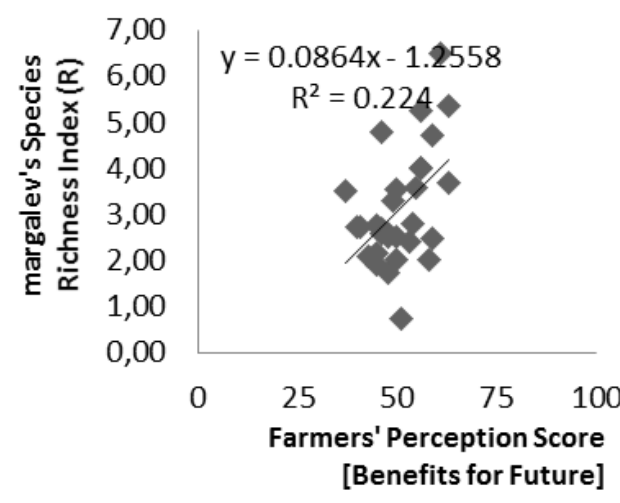

A



B

Figure 3. Effect farmers' positive perception (Score future benefits) from their agroforestry system on actual vegetation diversity: the richness index of trees species (A) and the diversity index of trees species (B) 


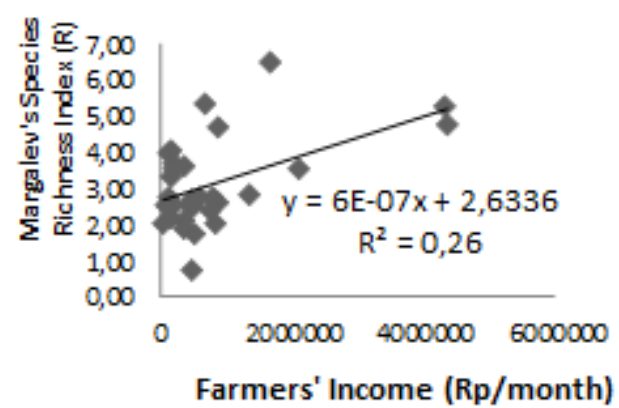

$\mathbf{A}$



B

Figure 4. The effect of farmers' income on the richness of trees species (A) and trees density (B)

Based on SLA, characteristics of livelihood related to capitals in every site showed the level of communities' welfare. Specifically, the one indicator of communities' welfare in agroforestry systems was farmers' income. The contribution of farmers income to the variation of species richness index in agroforestry systems was about $30 \%$ and to the tree density just $11.5 \%$ (Fig.4). It means that farmer income had important role in supporting biodiversity conservation.

The results also revealed that farmers' income influenced species richness and tree densities income. Farmers who had higher income in Sigi had more plant species in their land. Likewise, the farmer's income statistically and significantly influenced the management of tree density. The correlation between farmers' income and tree species richness index was very significant $(\mathrm{r}=0.51)$, and between farmers' income and tree, density was also very significant $(\mathrm{r}=0.36)$. The results of this research were in agreement with that of Regmi (2003) which explained that agroforestry had the important role of increasing farmers' incomes. In addition, it can increase tree species diversity, as shown by Tilman (2001) and Naeem (1994), who found that there were positive correlations between higher tree species diversity and productivity, especially for aboveground biomass. Clough (2011) also supported the concept that agroforestry, practiced by small-scale farmers in small areas, such as cacao-based agroforestry, offers opportunities to increase high crop production, as well as higher biodiversity.

It can be concluded that agroforestry systems in Sigi District, Central Sulawesi, Indonesia had high plant species diversity and the diversity increased with increasing elevation, up to $1400 \mathrm{~m}$ above sea level. The increasing accessibility did not affect vegetation diversity. The species diversity had significantly positive correlation with perception of farmers regarding the values of agroforestry systems and the farmers' income. We recommend that further research and efforts should be conducted to maintain the sustainability of agroforestry systems in this area.

\section{ACKNOWLEDGEMENTS}

This research has been carried out as an initiation of MAROSO (Making Resilience for Sigi Civil Society Organization) project activities, which was a collaboration project of research, for the baseline survey, related to the issue of climate change, its impact on the environment, and the communities' welfare, between the Faculty of Agriculture, Brawijaya University and World Vision for Indonesia (WVI) Area Development Program (ADP) SIGI, funded by AusAID. Foremost, we would like to thank the MAROSO team, especially Widianto, Iva, Didik Suprayogo, Yayuk, Iwan, Mashudi, Cahyo Prayogo and the entire MAROSO team from WVI staff ADP Sigi who were involved in the field, for the support, both material and spiritual. We are also thankful for the cooperation of the various parties who have helped in the socialization program of our research and for technical support in the field i.e regional staff of the Women's Coalition for Indonesia Central Sulawesi- AusAID, especially for Ms. Dewi and Maspa; all staff at Herbarium Celebense Palu, Tadulako University; staff of the Soil Biology and Soil Physics Laboratory at the Soil Department, Faculty of Agriculture, Brawijaya University especially Sarkam, Ngadirin and Sukadi; all staff of the Soil Laboratory at the Faculty of Agriculture, Tadulako University, especially Sukma and Subyan.

\section{REFERENCES}

Aguilar-Santelises R, Del Castillo RF. 2013. Factors affecting woody plant species diversity of fragmented seasonally dry oak forests in the Mixteca Alta, Oaxaca, Mexico. Revista Mexicana de Biodiversidad 84: 575-590.

Ahmed SE, Lees AC, Moura NG, Gardner TA, Barlow J, Ferreira J, Ewers RM. 2014. Road networks predict human influence on Amazonian bird communities. Proc Biol Sci 281 (1795). DOI: 10.1098/rspb.2014.1742.

Altieri, M.A. 1999. The ecological role of biodiversity in agroecosystems. Agric Ecosyst Environ 74 (1-3): 19-30. 
Bos MM, Sporn SG. 2013. Biodiversity conservation in cacao agroforestry systems. In: Simonetti JA. et al. (ed.) Biodiversity conservation in agroforestry landscapes: challenges and opportunities. Editorial Universitaria, Santiago.

Cannon CH, Summers M, Harting JR, Kessler PJA. 2007. Developing conservation priorities based on forest type, condition, and threats in a poorly known ecoregion: Sulawesi, Indonesia. Biotropica 39 (6): $747-$ 759

Clough Y, Barkmann J, Juhrbandt J, Kessler M, Wanger TC, Anshary A, Buchori D, Cicuzza D, Darras K, Putra DD, Erasmi S, Pitopang R, Schmidt C, Schulze CH, Seidel D, Steffan-Dewenter I, Stenchly K, Vidal S, Weist M, Wielgoss AC, Tscharntke T. 2011. Combining high biodiversity with high yields in tropical agroforests. Proc Natl Acad Sci USA 108 (20): 8311-8316.

Collins WW, Qualset CO. (eds.). 1999. Biodiversity in Agroecosystems. CRC Press, Boca Raton, FL.

Hairiah K. 2013. Pertanian Masa Depan: Agroforestry, Manfaat dan Layanan Lingkungan. FP UB -World Agroforestry CentreMasyarakat Agroforestri Indonesia. Universitas Brawijaya, Malang. [Indonesian]

Halladay P, Gilmour DA. 1995. Conserving Biodiversity Outside Protected Areas: The Role of Traditional Agro-ecosystems. IUCNThe World Conservation Union, Gland, Switzerland.

Hiwot TG, Zewdu T, Birhane E. 2014. Effect of human settlement and altitude on rangeland herbaceous species biodiversity and productivity in Kafta- HumeraWoreda, Tigray, Ethiopia. J Environ Earth Sci 4 (15): 108 - 114.

Kessler M, Keßler PJA, Gradstein SR, Bach K, Schmull M, Pitopang R. 2005. Tree diversity in primary forest and different land use systems in Central Sulawesi, Indonesia. Biodiv Conserv 14: 547-560.

Naeem S, Tompson LJ, Lawler SP, Woodfin RM. 1994. Declining biodiversity can alter the performance of ecosystem. Nature 368: 734737.

Nair, PKR, Garrity D (ed.). 2012. Agroforestry: The Future of Global Land Use. Springer, Dordrecht.

Regmi, BN. 2003. Contribution of Agroforestry for Rural Livelihoods: A Case of Dhading District, Nepal. Paper presented at The International Conference on Rural Livelihoods, Forests and Biodiversity. Bonn, Germany.

Tarvirdizadeh H, Nikooy M, Pourbabaei H, Naghdi R. 2014. Effects of road construction on biodiversity and composition of herbaceous species cover, Asalem forest, northern Iran. Forestry Ideas 2 (48): 157-169.

Tilman D, Reich PB, Knops J, Wedin D, Mielke T, Lehman C. 2001. Diversity and productivity in a long-term grassland experiment. Science 294: 843-845.

Vandermeer, J, Perfecto, I. 1995. Breakfast of biodiversity: the truth about rainforest destruction. Food First Books, Oakland, USA.

Votsi N-E, Mazaris AD, Kallimanis AS, Zomeni MS, Vogiatzakis IN, Sgardelis SP, Pantis JD. 2012. Road effects on habitat richness of the Greek Nature 2000 network. Nature Conserv 1: 53-71. 